\title{
Reading the history of bastion castles in Galicia (Eastern Europe) using the Friedrich von Mieg map
}

\author{
O. Tikhonova \\ Faculty of Architecture, Lisbon Technical University, Portugal
}

\begin{abstract}
The purpose of this research is to show the usefulness of cartographic materials in research, namely cadaster maps; in particular for studying landscape architecture, settlements planning, and localization of military objects on the territory. Primary attention in this paper is paid to Map of the Kingdom of Galicia and Lodomeria as a part of cadaster maps made in the First Military Survey in 1763-1787 by Officer Friedrich von Mieg. The maps are serviceable for studying military architecture because the author, Friedrich von Mieg, gave particular attention to locating military objects during the map's creation. The author of the research used this map to establish the position of bastion castles and their quantity in the territory of Galicia (the historical and geographic region in Eastern Europe). The nucleus of historical Galicia lies within the modern parts of Poland (Lesser Voivodeship, Subcarpathian Voivodeship, and Silesian Voivodeship) and western part of Ukraine (Lviv, Ternopil and Ivano-Frankivsk region). At the end, the researcher has defined 39 bastion castles on the territory understudying. Besides, the scholar has found 40 unspecified castles that need further investigation because it was hard to identify exactly their type using the map. These results will help the author undertake deeper research about the history and fate of these castles. The discovery gives a clear picture about the castles with bastion profile on the territory and, also, can help find the current location of strongholds and make recommendations about their rehabilitation.
\end{abstract}

Keywords: map of the Kingdom of Galicia and Lodomeria, bastion castles, cadaster maps. 


\section{Introduction}

There are a lot of helpful tools for architectural studies such as descriptions, maps, and iconography in archives. In the case of studying a group of objects on a determined territory or in studies of landscape design the most powerful tool is cartography.

The First Military Mapping Survey is one of the most outstanding achievements in cartography in the XVIII century. In 1763-1787 Habsburg officer Friedrich von Mieg led map-making of the Habsburg Monarchy into the frame of large-scale topographic surveying [1]. That is why the resultant maps known as "Friedrich von Mieg maps" for Ukrainian and Polish researchers. The original name is "Josephinische Landesaufnahme" in honor of Emperor Joseph II their implementer [2].

The maps are an excellent source for beginning research in the field of military architecture because their creators paid particular attention to the localization of fortifications. The author in this research wants to investigate a part of this map called the Map of the Kingdom of Galicia and Lodomeria ("Karte des Königreichs Galizien und Lodomerien") in search for bastion castles of the XVII century.

The comprehensive research of bastion fortifications on the territory of Galicia using the "Friedrich von Mieg maps" was not made before because of difficulties with source accessibility and the vast area of the investigation. Initially, Habsburg Imperia had kept the map in secret inasmuch of military importance and even in our time it has not released. Nowadays, the originals of Map of the Kingdom of Galicia and Lodomeria remains in manuscripts in the Archives of War in Vienna (Kriegsarchiv), ref. BIXa.390. The map consists of 413 large sheets (basic size: $24 \times 16$ inches, or about $63 \times 42 \mathrm{~cm}$ ) [2].

The result of the research is the localization of bastion castles on the modern territory and creation of the map with detected objects that will help in author's research about the history of castles with a bastion profile in the Galicia region. Furthermore, the results can be used in tourism to create Castles Trail in Galicia, in rehabilitation to preserve the remains, in archeology to find the remains, and in urban planning to create preservation zones.

\section{Literature review}

Many scholars such as Zachariasz [3-5], Kowalska [6], Petryszyn [7], Bogdanowski [8, 9], Czyżewska [10], Stoksikowna [11] and Fedunyk [12] talked about the history, applicability and usefulness of Galician cadaster for research.

Zachariacz [5] in her research says about the importance of archival cartographic materials for today's studying in landscape architecture and projects of rehabilitation of architectural complexes. She studied the cadastral maps, especially the part of Austrian land cadaster from the mid-19th century. In her previous works from 1996-2000, especially in her Ph.D. thesis, Agata Zachariasz studied cadaster plans for the purpose of studying gardens. In her research Zachariasz [4], she gave the definition of the word "cadaster", studied work of 
other scholars in this field, overviewed Austrian and Galician cadaster and their components, explained the legend of the map and gave methodology of cadaster research.

Author Kowalska [6] studied different old and new cartographic materials as sources of information about changes in the landscape. In her research, she presented the history of the development of cartographic materials and analysed the following maps: Polish land register, topographic maps, cadastral map, orthophotomaps, local spatial plan, and study of conditions and directions of space development.

Ukrainian scholar, Halyna Petryshyn [7] in her book "Map Fon Mieg as a source to understand the city" gives the description of the "Friedrich von Mieg maps," their content, and structure. In her book, she paid attention to the Ukrainian part of the Kingdom of Galicia and Lodomeria. The scholar gave the legend of the map and example of Zolochiv city description as it was in original manuscripts of the map. Besides, she created a table with new and old names of towns and villages, their status, and section number of original map as it is in the original manuscripts. Halyna Petryshyn provided a copy of fragments of plans of all the cities listed in her table (212 cities, towns and villages from Ukrainian part of the map) in the double scale 1:14400, except cities Lviv, Busk, and Gorodok that gives in original scale 1:28800.

Janusz Bogdanowski [9] in his work used cadaster plans to study Italian gardens and palaces under Cracow. Czyzewska used cadaster plans as a source of spatial information in cultural value. Stoksikowna studied Galician cadaster genesis, history and legacy in general.

Zenoviy Fedunyk [12] in his research analysed castles, fortresses and sacral building on the territory of Ivano-Frankivsk region using the fragments of "Friedrich von Mieg maps" which are in the book of Halyna Petryshyn. As a result, he found four bastion castles in this region: Castle in Bolekhiv, Chernelytsia, Verkhnia Lypytsia, and Mariampil.

\section{Methodology}

Research design lays on the analysis of the topographical map of The Kingdom of Galician and Lodomeria (1779-1783) in search for bastion castles. The author checked all settlements on the map that have any mention in the literature about evidence of fortifications in search for castles with bastion profile. Likewise, author checked all big towns and principal villages in the XVII century.

After analysis of the data, the author has got a clear "picture" of localization of bastion castles on the territory under investigation.

\section{Analysis/results}

The author has evaluated 312 settlements on Galician cadaster map sheets (17791783 ) in search for bastion castles of the XVII century. This lists the research made 
according to mentions of castles in different sources from prominent researchers in the field of fortifications, such as Adamchyk, Lozinski, Pshyk, Guillaume Le Vasseur de Beauplan map and others that talked about the even possibility of existing castles in that place. At the end, the author made a map of Galician region with labeled towns where she has found bastion type Castles using the Friedrich von Mieg Map (fig. 1).

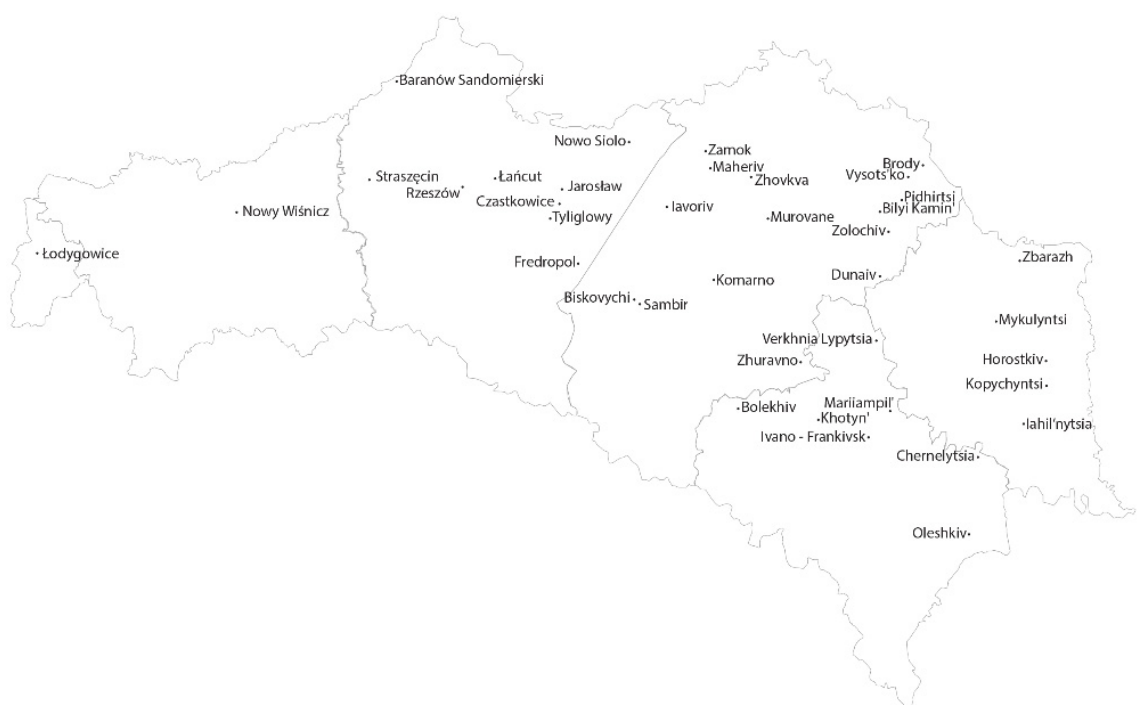

Figure 1: Scheme with detected bastion castles in the Galicia region using the Friedrich von Mieg map.

In addition, the scholar has created table 1 with handmade reproductions of map fragments where the author has found castles with a bastion profile. The table gives the name of the checked settlement and provides the handmade sketch of the plan.

\section{Discussion}

After analysis of the Galician map of the First Military Survey, the author has found 39 bastion castles of the XVII century in the territory of investigation. There were 11 castles in Poland, namely 1 in Lesser Voivodeship, 9 in Podkarpackie Voivodeship, and 1 in Silesian Voivodeship; and 28 castles in Ukraine, namely 7 in Ivano-Frankivsk region, 15 in Lviv region and 6 in Ternopil region. In addition, 19 castles were found in Poland and 21 in Ukraine that need further investigation. In these cities the author found a stronghold, but it is hard to determine the type of the fortification. 
Table 1: Handmade sketches of fragments of the Kingdom of Galician and Lodomeria map (1779-1783) with found bastion castles (reproduced by the author).

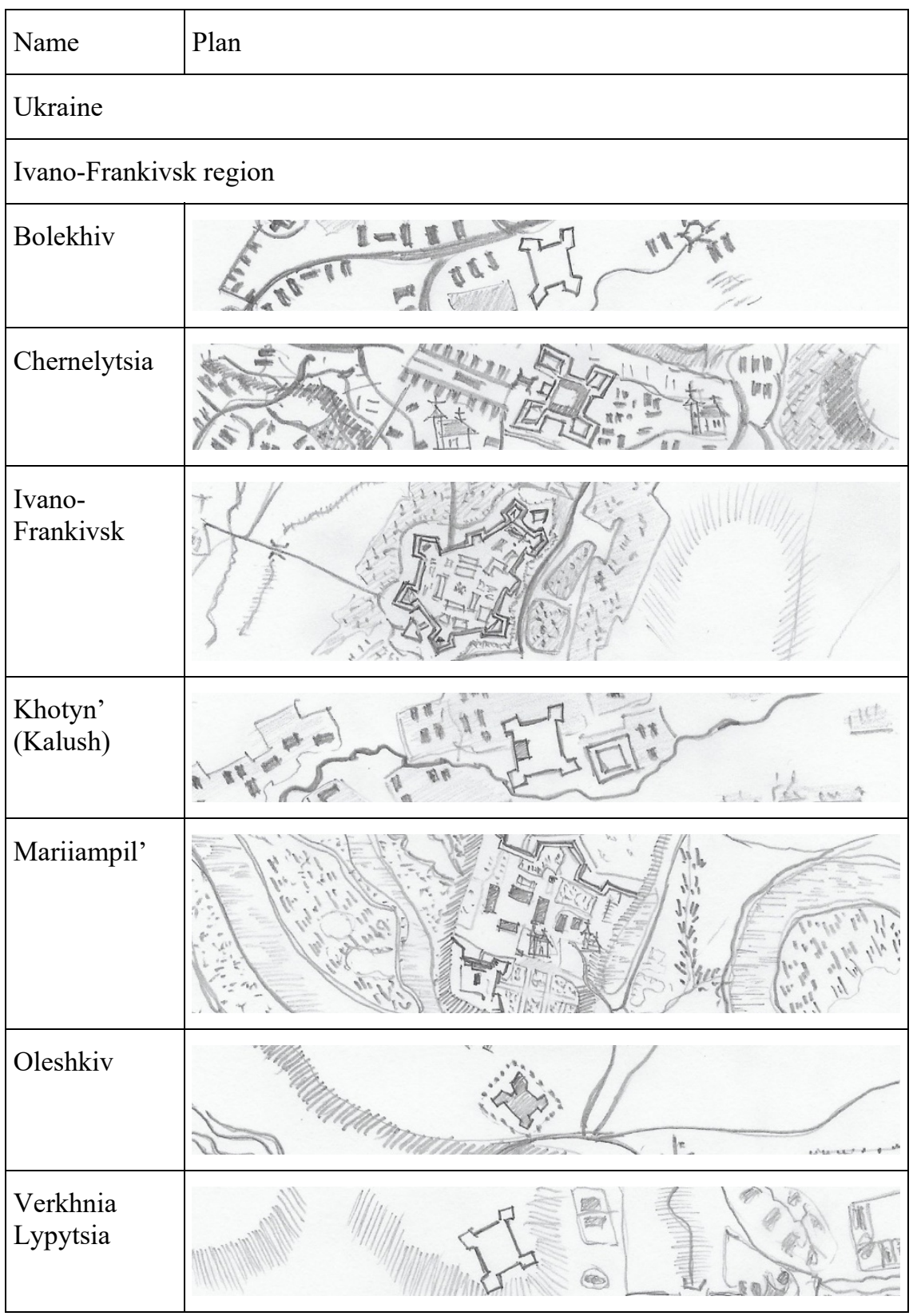


78 Defence Sites III: Heritage and Future

Table 1: Continued.

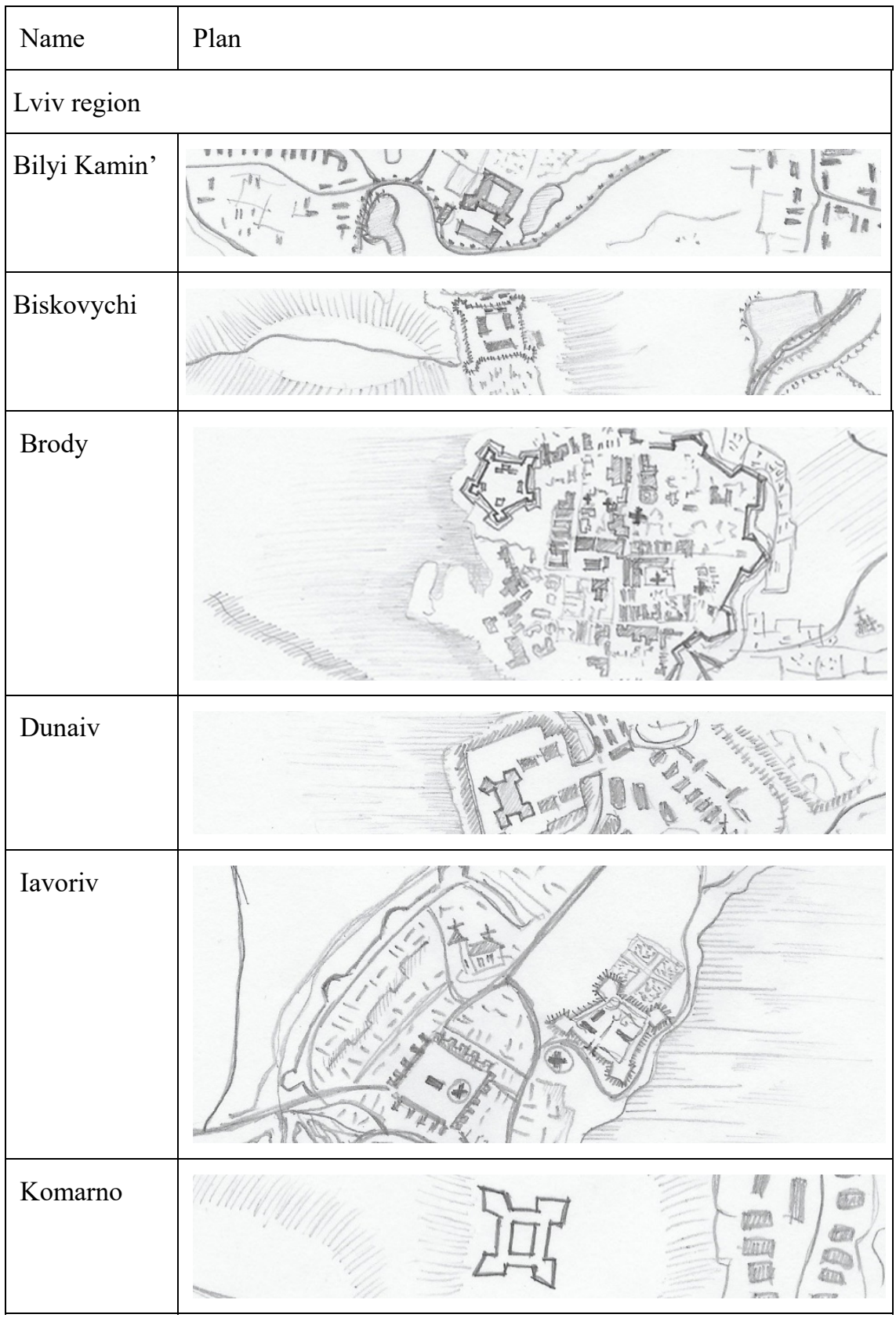


Table 1: Continued.

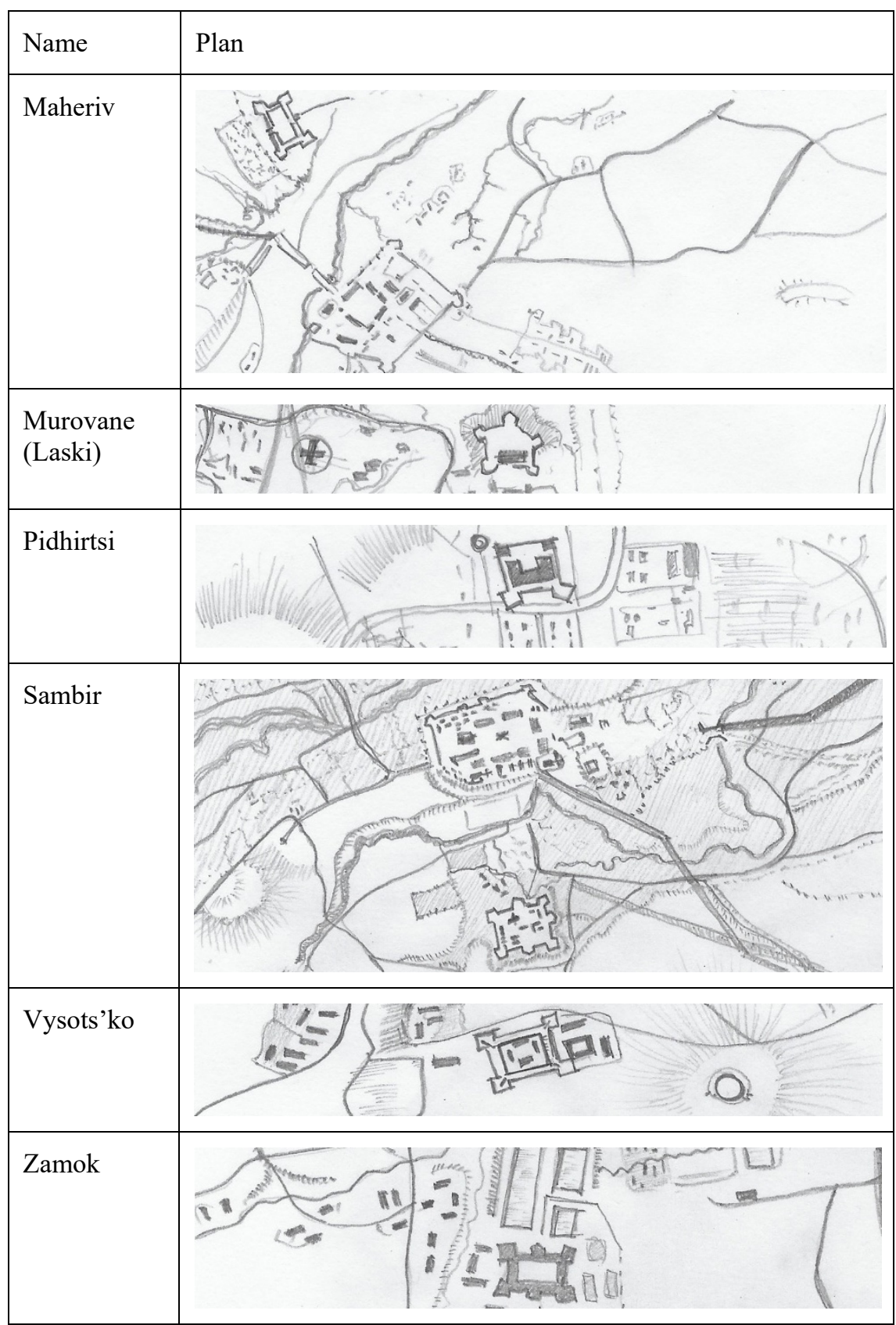


80 Defence Sites III: Heritage and Future

Table 1: Continued.

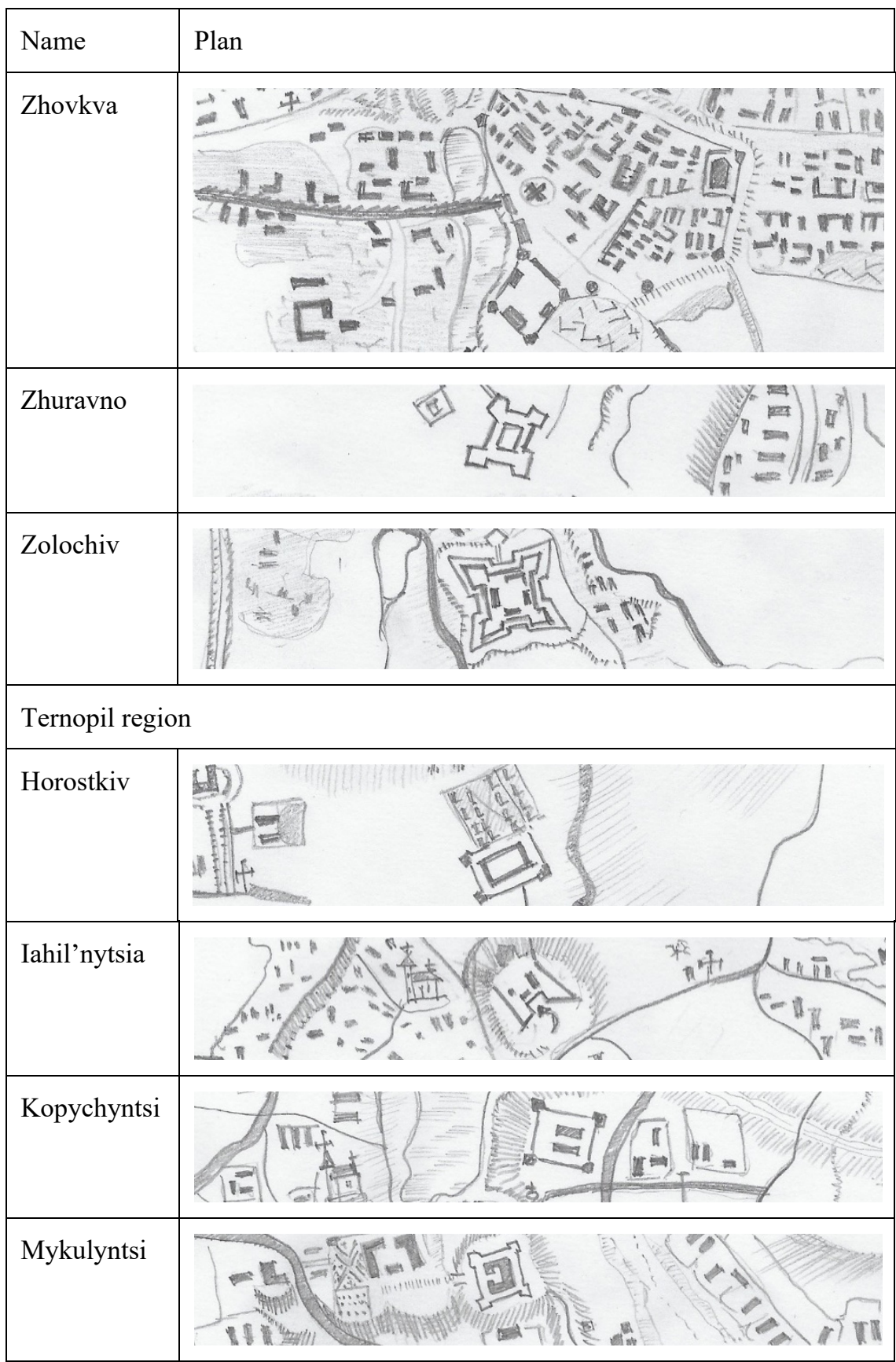


Table 1: Continued.

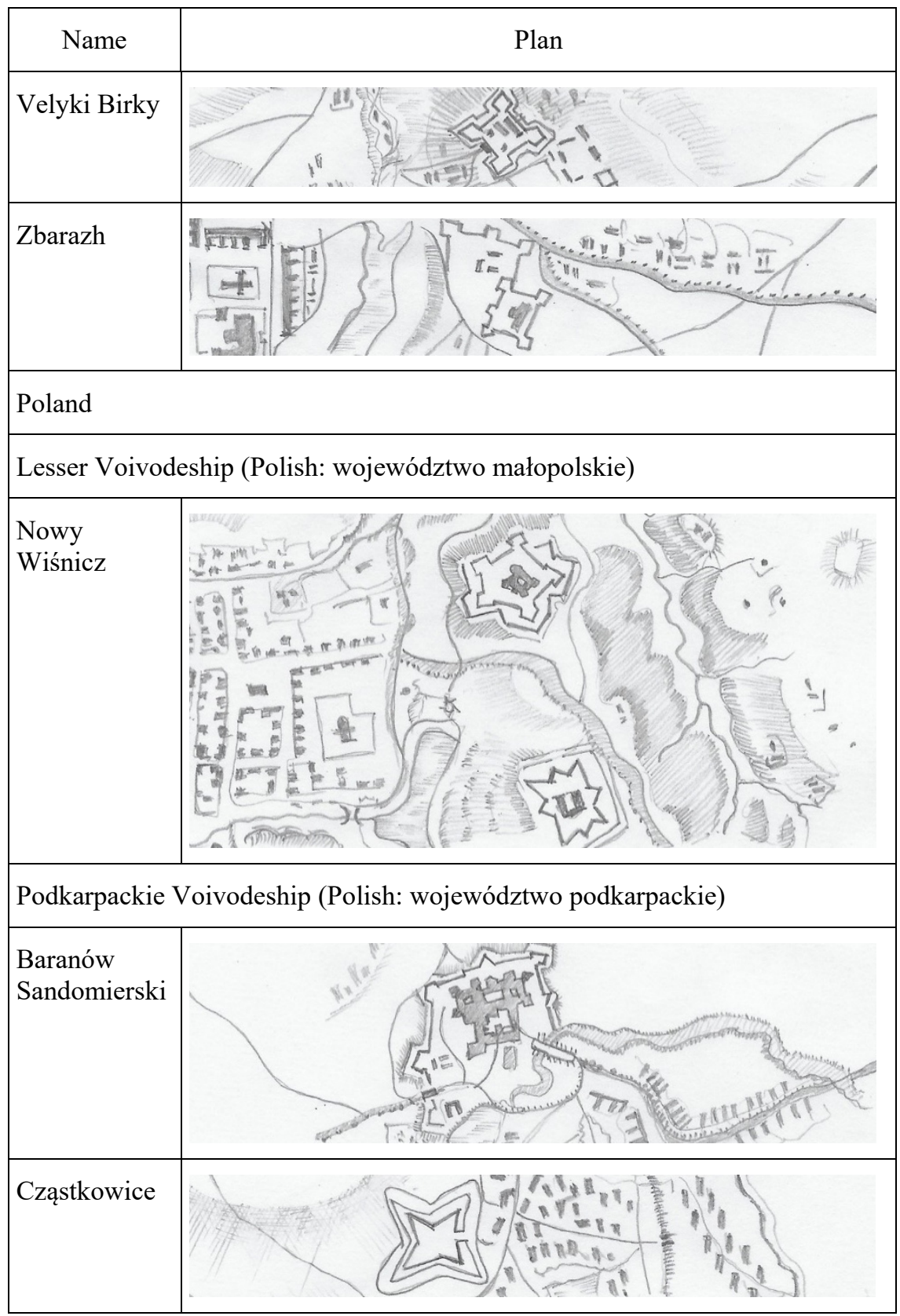


82 Defence Sites III: Heritage and Future

Table 1: Continued.

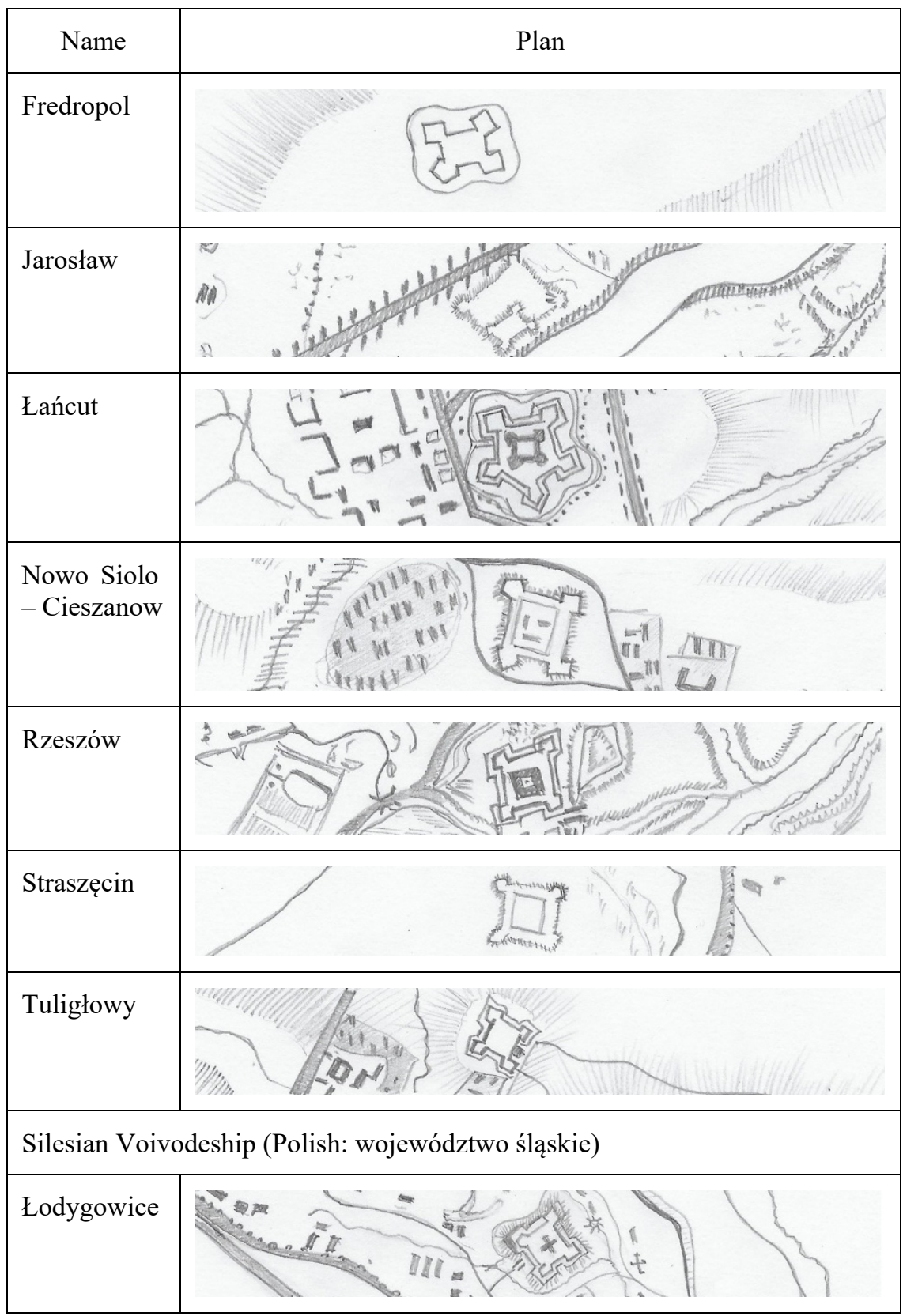




\section{Conclusion}

The landscape is dynamical, because the planning of the cities and villages changing with time, it reflects the historical and cultural shifts in the settlement life, especially in the time of wars and reformations. Moreover, the best way to observe these changes is studying cartographical materials. Officer Friedrich von Mieg made the best cartographical materials of XVIII century in a frame of the first Military Survey that took place between 1763 and 1787. These maps are vital for recreating the history of fortifications and detection their location. It can help to find remains of fortifications and study them more careful. In this research, the author has presented studies of bastion fortifications using just one piece of this excellent cartographic work, Map of the Kingdom Galicia and Lodomeria.

The results of this research is a starting point for future studies about the history of these castles, their characteristics, current location, state, and rehabilitation methods, for those that exist now. Furthermore, using bibliographic materials, archival descriptions, and studies of scholars on bastion castles, settlements for evidence of bastion castles should be checked where the author left as a city with the undefined type of fortifications.

\section{References}

[1] Liebenberg, E., Collier, P. \& Torok, Z.G., History of Cartography, Springer Science \& Business Media, p. 19, 2013.

[2] Bukowski,W., \& Janeczek, A., Mapa józefińska Galicji (1779-1783) w przededniu edycji. Przedmiot i założenia programu wydawniczego. Studia Geohistorica, 01(2013), pp. 91-112, 2013.

[3] Zachariasz, A., "Ogrody angielskie" Beskidu Nieskiego i Pogorza przedstawione na planach katastralnych (Chapter 2). Rzeszowska Teka Konserwatorska,ed. A. Laskowski, Regionalny Ośrodek Studiów i Ochrony Środowiska Kulturowego: Rzeszow, pp. 227-256, 2000.

[4] Zachariasz, A., Odczytywanie historii zapisaney w krajobrazie. 2007. Online. http://ptip.org.pl/download/files/RG2007z8-Zachariasz.pdf

[5] Zachariasz, A., Przydatność archiwalnych źródeł kartograficznych dla współczesnych badań krajobrazowych. 2012. Online. www.krajobraz.kulturowy.us.edu.pl/publikacje.artykuly/16.kartografia/1.r ed.\%20i\%20spis.kartografia.pdf

[6] Kowalska, M., Opracowania kartograficzne jako źródła informacji o krajobrazie. Infrastruktura i Ekologia Terenów Wiejskich, 3(3), pp. 89-103, 2013.

[7] Petryshyn, H., "Karta F. fon Miga” (1779-1782) iak dzherelo do mistoznavstva Halychyny, L'vivs'ka politekhnika: Lviv, 2006.

[8] Bogdanowski, J., Ogrody włoskie pod Krakowem. Zeszyt specjalny, 1(1), pp. 59-121, 1966.

[9] Bogdanowski, J., Podkrakowskie założenia dworskie w świetle planów katastralnych (1848). Dwór polski w XIX wieku. Zjawisko historyczne $i$ kulturowe, 3(1), pp. 51-71, 1995. 
84 Defence Sites III: Heritage and Future

[10] Czyżewska, A., Kataster jako źródło informacji o przestrzennych wartościach kulturowych. Synteza kulturowych wartości przestrzeni państwa polskiego: problem badawczy Ministerstwa Kulturyi Sztuki. Wokót problemu badawczego, 4(4), pp. 7-34, 1991.

[11] Stoksikowna, J., Galicyjski kataster gruntowy jego geneza, dzieje i spuscizna aktowa. ARCHEION, LXIII, pp. 165-187, 1975.

[12] Fedunyk, Z., Fortetsi, zamky ta inkastelovani sporudy Prykarpattia na karti Fridrikha fon Miha. Proc. Of the $3^{r d} U k r$. Conf. On Archeology and Fortifications of Serednie Podnistrovia, ed. S. Stravinskyi, Medobory: Kam'ianets-Podilskyi, pp. 166-173, 2013. 